OPEN ACCESS

Edited by:

Anna Lupon,

Spanish National Research

Council, Spain

Reviewed by:

Xuesong Zhang,

Pacific Northwest National Laboratory

(DOE), United States

Allison Herreid,

University of New Hampshire,

United States

*Correspondence:

Sophie A. Comer-Warner

s.comer-warner@bham.ac.uk

Specialty section

This article was submitted to

Water and Critical Zone,

a section of the journal

Frontiers in Water

Received: 15 February 2021

Accepted: 09 June 2021

Published: 21 July 2021

Citation:

Comer-Warner SA, Blaen PJ,

Brekenfeld N, Gooddy DC, Lovell C,

Khamis K, Bryden $A$ and Krause $S$

(2021) Advection Not Dispersion and

Transient Storage Controls Streambed

Nutrient and Greenhouse Gas

Concentrations.

Front. Water 3:668183.

doi: 10.3389/frwa.2021.668183

\section{Advection Not Dispersion and Transient Storage Controls Streambed Nutrient and Greenhouse Gas Concentrations}

\author{
Sophie A. Comer-Warner ${ }^{1 *}$, Phillip J. Blaen ${ }^{1,2}$, Nicolai Brekenfeld ${ }^{1}$, Daren C. Gooddy ${ }^{2}$, \\ Christopher Lovell ${ }^{3}$, Kieran Khamis ${ }^{1}$, Alexandra Bryden ${ }^{1}$ and Stefan Krause ${ }^{1,2}$ \\ ${ }^{1}$ School of Geography, Earth and Environmental Sciences, University of Birmingham, Birmingham, United Kingdom, \\ ${ }^{2}$ Birmingham Institute of Forest Research, University of Birmingham, Birmingham, United Kingdom, ${ }^{3}$ Lucideon, \\ Stoke-on-Trent, United Kingdom
}

Streams and rivers are globally important in the carbon and nitrogen cycles due to high carbon and nitrogen turnover rates and contribute disproportionately to global greenhouse gas (GHG) emissions relative to their areal coverage. The hyporheic zone may be a hotspot of biogeochemical reactivity within fluvial ecosystems resulting in high rates of nutrient attenuation and associated GHG production. Controls on streambed nutrient cycling and particularly GHG production remain insufficiently understood. In this study, porewater concentrations of nutrients $\left(\mathrm{NH}_{4}^{+}, \mathrm{NO}_{3}^{-}, \mathrm{NO}_{2}^{-}\right)$and $\mathrm{GHGes}\left(\mathrm{CO}_{2}\right.$, $\mathrm{CH}_{4}, \mathrm{~N}_{2} \mathrm{O}$ ) were measured alongside surface water breakthrough curves (BTC) of conservative (uranine) and reactive tracers [resazurin (raz)-resorufin (rru)] to provide insights into often assumed correlations between in-stream advective transport and transient storage metrics, and streambed biogeochemistry. Streambed biogeochemical concentrations were significantly correlated with advective transport time but not with dispersion and transient storage. The effect of advective transport time varied between chemical species, with $\mathrm{NH}_{4}^{+}, \mathrm{CO}_{2}$, and $\mathrm{CH}_{4}$ exhibiting positive correlations and $\mathrm{NO}_{3}^{-}$, $\mathrm{NO}_{2}^{-}$, and $\mathrm{N}_{2} \mathrm{O}$ displaying negative correlations with advective transport time and vice versa for long-term storage. These findings increase knowledge of the relationship between hydrological drivers and streambed chemistry, potentially highlighting areas of the streambed expected to have elevated nutrients and GHGs. This improved understanding may allow chemical species to be effectively targeted by morphological restoration, which will aid in effective pollution and climate remediation.

Keywords: nutrient, greenhouse gas, streambed, advective transport, transient storage, dispersion, sediment, tracer

\section{INTRODUCTION}

Streams and rivers play an important role in global biogeochemical cycling, processing large proportions of the carbon and nitrogen entering them annually (Seitzinger et al., 2006; Cole et al., 2007; Trimmer et al., 2012). Streams can perform important ecosystem functions, reducing nitrogen pollution through nutrient attenuation, and improving ecosystem health, water quality, and stream habitats (Triska et al., 1993; McMahon and Böhlke, 1996; Brunke and Gonser, 1997). 
Crucial ecosystem benefits are often accompanied by increases in greenhouse gas (GHG) production from aerobic and anaerobic respiration, and various reactions oxidizing and reducing nitrogen (Kendall, 1998; Baker et al., 2000; Wrage et al., 2001; Lansdown et al., 2014). Greenhouse gas emissions from streams and rivers are globally significant (Anderson et al., 2010; Beaulieu et al., 2011; Raymond et al., 2013; Stanley et al., 2016), with estimated annual fluxes of $1.8 \mathrm{Pg} \mathrm{CO}_{2}-\mathrm{C} \mathrm{yr}^{-1}, 26.8 \mathrm{Tg} \mathrm{CH}_{4}-\mathrm{C}$ $\mathrm{yr}^{-1}$, and $0.68 \mathrm{Tg} \mathrm{N}_{2} \mathrm{O}-\mathrm{N} \mathrm{yr}^{-1}$ (Beaulieu et al., 2011; Raymond et al., 2013; Stanley et al., 2016).

Within streams and rivers the majority of metabolic activity and biogeochemical cycling occurs within the sediment, resulting in "hotspots" of nutrient attenuation and GHG production in these areas (McClain et al., 2003; Lautz and Fanelli, 2008; Trimmer et al., 2012). Mixing of groundwater and surface water can create conditions for increased reactivity due to substrate supply and increased residence times, thus increasing the time available for reactions to occur (Findlay, 1995; Boulton et al., 1998; McClain et al., 2003; Lautz and Fanelli, 2008; Pinay et al., 2009; Boano et al., 2010; Krause et al., 2011; Zarnetske et al., 2011). Solutes in surface water typically enter and leave the streambed through hyporheic exchange flowpaths resulting in transient storage within the sediments (Bencala and Walters, 1983; Bencala et al., 2011).

Similarly, "hotspots" and "hot moments" of reactivity may occur in surface flow due to changes in advective transport times and transient storage increasing residence times of water and its chemical constituents. Advective transport times, dispersion and transient storage can, therefore, be important controls on biogeochemical cycling, within both surface and sub-surface flows (Mulholland et al., 1997; Boulton et al., 1998; Gooseff et al., 2005; Pinay et al., 2009; Zarnetske et al., 2011) and are controlled by local hydrology and geomorphology (Harvey and Bencala, 1993; Brunke and Gonser, 1997; Jin et al., 2009; Schmadel et al., 2016).

Conservative tracers (e.g., chloride, uranine) are commonly used to determine advective transport times, dispersion and transient storage indices in streams and rivers, which enable these parameters to be compared between streams, sub-reaches, and differing geomorphologies (Harvey and Wagner, 2000; Gooseff et al., 2005; Mason et al., 2012; Ward et al., 2013a,b; Schmadel et al., 2016). Reactive tracers [e.g., resazurin (raz), nitrate] may be used to investigate specific processes such as aerobic respiration and nutrient uptake (Haggerty et al., 2009; Zarnetske et al., 2011; González-pinzón et al., 2012; Harvey et al., 2013; Knapp et al., 2018), providing additional information on reactive solute transport.

Despite the known importance of streambed biogeochemical cycling, understanding of controls on biogeochemistry in these environments remains insufficiently understood. Here, we investigate the influence of advective transport times, dispersion and transient storage, and aerobic microbial respiration on streambed chemistry within an agricultural stream. We aim to determine the relationship between hydrological metrics and aerobic respiration, and streambed chemistry and if the relationships (positive or negative) vary with the concentration of chemical constituents. We hypothesize that advective transport, dispersion and transient storage, and ecosystem respiration drive variations in chemical concentrations within the streambed and that the direction of the relationship will vary depending on chemical species.

\section{MATERIALS AND METHODS}

\section{Study Site}

Experiments were conducted over four seasons (July 2016, October 2016, February 2017, March 2017) in the Wood Brook, a small, lowland stream at the Birmingham Institute of Forest Research, Staffordshire, UK (https://www.birmingham.ac. uk/research/activity/bifor/index.aspx). Each sampling campaign included a solute tracer experiment and streambed porewater sampling. The catchment upstream of the monitoring location is dominated by arable land (predominantly potato and winter wheat crops; Blaen et al., 2017a) with patches of deciduous woodland (Figure 1). The experimental reach consisted of a $1 \mathrm{~km}$ section starting in arable land, before flowing along the border between arable land and a patch of deciduous woodland, and into the woodland itself. In channel sediment varied between the upstream section, which contains sand-dominated sediment and the downstream section, which contains gravel-dominated sediment (indicated by the black bar in Figure 1). The regional groundwater aquifer is Permo-Triassic sandstone, overlain with $10 \mathrm{~m}$ thick glacial till deposits with $15-60 \mathrm{~cm}$ of sandy clay sediment on top of those (Blaen et al., 2017a). The average channel width was $2 \mathrm{~m}$ and average water depth was $13.9 \mathrm{~cm}$. A continuous monitoring station was located $\sim 2 \mathrm{~m}$ downstream of site D (Figure 1) and measured a suite of parameters including river level (converted to discharge using a stage-discharge rating curve), specific conductance, temperature, dissolved oxygen, $\mathrm{pH}$, dissolved organic carbon, and $\mathrm{NO}_{3}^{-}$(Supplementary Figure 1). The stream discharge measured at the continuous monitoring station ranged from $5 \mathrm{~L} \mathrm{~s}^{-1}$ in October to $40 \mathrm{~L} \mathrm{~s}^{-1}$ in February. Further details on how parameters were measured, including the stage-discharge rating curve, are provided in Blaen et al. (2017a).

\section{Solute Tracer Experiment} In-stream Tracer Injections

A slug injection of both conservative (uranine) and reactive (resazurin) tracers was conducted seasonally $250 \mathrm{~m}$ upstream of the first fluorometer ( $180 \mathrm{~m}$ upstream in July) (Blaen et al., 2018). Tracers were dissolved in stream water immediately before injection so that a tracer-in-solution method was used (Moore, 2005). $1.2 \mathrm{~g}$ of uranine and $8 \mathrm{~g}$ of resazurin were injected in October, February, and March, and $2 \mathrm{~g}$ of uranine and $8 \mathrm{~g}$ of resazurin were injected in July. Quantities were chosen to ensure tracer detection by in-stream fluorometers (GGUN-FL30, Albillia Sàrl, Switzerland) (Lemke et al., 2013). In July, uranine concentrations at site A were higher than the fluorometer detector can analyse, therefore, the mass of uranine used was lower in the other seasons compared to July. Tracers were released at a distance upstream of the study reach long enough to ensure full mixing in the water column. The resazurin-resorufin "smart" tracer system has been widely used in streams over the past decade as a proxy for aerobic 


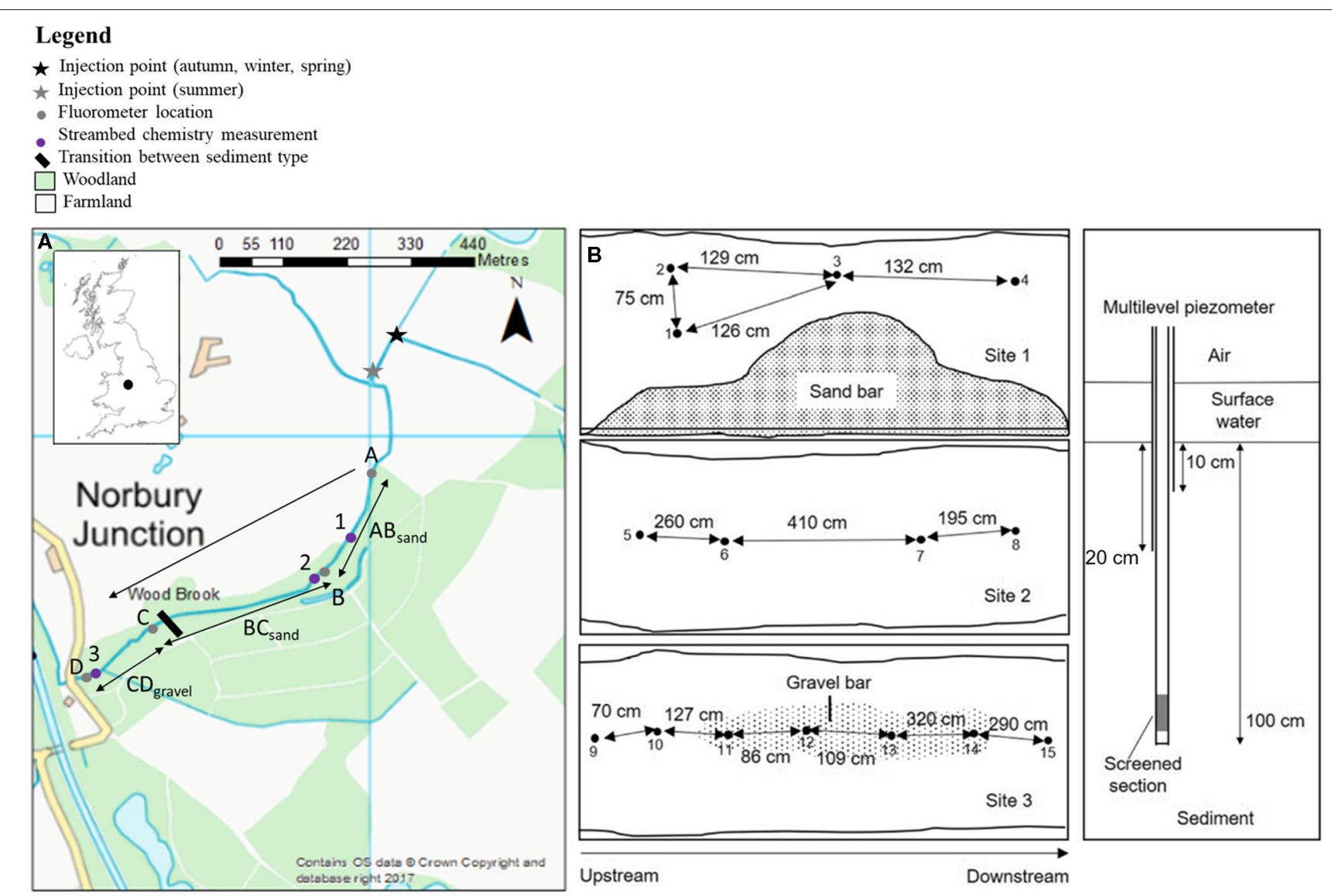

FIGURE 1 | (A) A map of the study site showing the location of the study site within the UK (inset) and the stream experimental sites within the catchment. A-D indicate the fluorometer locations and 1-3 indicate the streambed chemistry sampling sites and (B) The locations and sampler information of the multilevel mini-piezometers used for streambed chemistry sampling. Figure amended from Comer-Warner et al. (2020).

respiration (Haggerty et al., 2008, 2009; Knapp et al., 2018). Resazurin is irreversibly reduced to resorufin when used as a terminal electron acceptor by aerobic microorganisms, as both resazurin and resorufin are fluorescent dyes, their concentrations are easily determined through fluorometry (Haggerty et al., 2008). Subsequently, the rate of transformation of resazurin to resorufin measured through stream tracer experiments provides an estimate of whole-stream aerobic respiration (Gonzálezpinzón et al., 2014).

Tracer injections were performed in late afternoon or early evening to minimize the possibility of tracer photo-degradation (Cai and Stark, 1997; Haggerty et al., 2008), the location of the stream within woodland also minimized photo-degradation through shading. Breakthrough curves (BTC) of uranine, resazurin, and resorufin were measured simultaneously at four sites A, B, C, and D (Supplementary Figures 2-4), creating three sub-reaches $\mathrm{AB}_{\text {sand }}$ (sand-dominated sediment), $\mathrm{BC}_{\text {sand }}$ (sanddominated sediment), and $\mathrm{CD}_{\text {gravel }}$ (gravel-dominated sediment) within the study reach (Figure $\mathbf{1}$ and Table 1). Breakthrough curves were measured in-situ using on-line field fluorometers (GGUN-FL30) capable of measuring uranine, resazurin, and resorufin simultaneously at 10 s resolution (Lemke et al., 2013), resulting in higher temporal resolution BTCs and increased information on BTC tailing. Different wavelengths were used to excite uranine, resorufin, and resazurin $(470,525$, and $570 \mathrm{~nm})$ so they were detected simultaneously with minimal interference from each other (Lemke et al., 2013). Fluorometer calibration (including cross-calibration) was performed in-situ immediately before injection to allow calibration with the stream water of the study site. The fluorescence intensity of uranine, resazurin, and resorufin is affected by $\mathrm{pH}$ below 7.5 (Lemke et al., 2013), the $\mathrm{pH}$ ranged between 7.4 and 8.6 during our experiments with only $4 \%$ of measurements below 7.5 (Supplementary Figure 1).

The resulting BTCs were corrected for variations in temperature and turbidity (Blaen et al., 2017b), data was selected from the relevant time period of the BTC, and was corrected for any drift in the tracer signal between the beginning and end of the BTC. The drift correction was applied by averaging the baseline concentration prior to the arrival of the BTC and correcting the BTC so that the baseline after the end of the tail had passed was equal to this initial baseline concentration. Where the BTC was clearly being detected (the arrival of the BTC could be seen) but the background concentration was below zero, the background was corrected to zero, likewise background concentrations above 


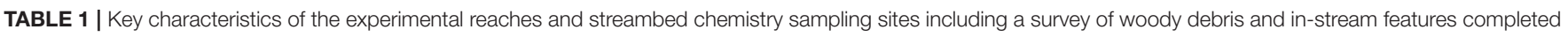
in July 2016.

\begin{tabular}{|c|c|c|c|c|c|c|c|c|c|}
\hline & Physical features & & & & & Dominant & & & \\
\hline Reach & Feature & Quantity & Slope $\left(\mathrm{mm} \mathrm{m}^{-1}\right)$ & Width (m) & Depth (cm) & Length (m) & Sediment type & Site & $d(0.9)(\mathrm{mm})$ \\
\hline $\mathbf{A B}_{\text {sand }}$ & Total woody debris features & 22 & -1.5 & 2.0 & 20.4 & 239.3 & Sand & 1 & 525.0 \\
\hline $\mathbf{B C}_{\text {sand }}$ & Total woody debris features & 11 & -4.0 & 1.9 & 10.8 & 289.2 & Sand & 2 & 627.1 \\
\hline $\mathrm{CD}_{\text {gravel }}$ & Total woody debris features & 20 & -14.1 & 2.2 & 10.5 & 165.1 & Gravel & 3 & 812.2 \\
\hline
\end{tabular}

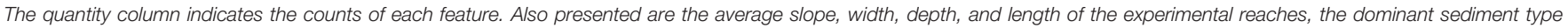
present in each reach, and the diameter that $90 \%$ of particles are smaller than $(\mu \mathrm{m})$ from grain size analysis of sediment sieved at $2 \mathrm{~mm}$.

zero were corrected down to zero as uranine, resorufin, and resazurin do not naturally occur in streams. Some background concentrations were negative because they were either below the limit of detection or because the calibration curve was not perfect close to zero.

\section{Calculation of Solute Transport and Storage Parameters}

We analyzed conservative BTCs through the determination of transport, and short- and long-term storage metrics following (Ward et al., 2013a; Schmadel et al., 2016) due to the high uncertainty and susceptibility to equifinality of parametric approaches to stream solute BTC analysis (e.g., Wagner and Harvey, 1997; Lees et al., 2000; Mason et al., 2012; Ward et al., 2013a). Details of the metrics and how they were calculated are given in Table 2, $t_{w}$ and TSI were normalized by dividing by $t_{a d}$ and the first temporal moment was normalized by the recovered transit time distribution (Schmadel et al., 2016). The window of detection represents the maximum tracer recovery time and provides the boundary between short-term and longterm storage (Harvey and Bencala, 1993; Harvey et al., 1996; Wagner and Harvey, 1997; Harvey and Wagner, 2000; Ward et al., 2013b), allowing determination of the maximum length of short-term storage processes captured by each tracer experiment. Due to some localized increases in storage, especially at site $\mathrm{C}$, $\Delta \mathrm{CV}$, and $\Delta \gamma$ values could often not be computed as this led to negative values of central moments; therefore, $\mathrm{CV}$ and $\gamma$ were used here instead. The final hydrological metrics used for the analysis in this study are highlighted in bold in Table $\mathbf{2}$ and are $\Delta M_{1}, \Delta t_{a d}, \Delta t_{w, \text { norm }}, \Delta T S I_{\text {norm }}, \mathrm{CV}, \gamma$, and $\Delta M_{\text {loss }}$.

The rate of transformation of resazurin-to-resorufin was used as a proxy for integrated whole-stream aerobic respiration. Following Knapp and Cirpka (2018) the zeroth temporal moments of resazurin and resorufin were normalized by those of uranine and the apparent transformation rate of resazurin to resorufin was calculated from the normalized zeroth temporal moments. The zeroth temporal moment is calculated from the integrals of the BTC (Knapp and Cirpka, 2018).

\section{Streambed Chemistry Porewater Sampling}

Porewater samples were collected seasonally from three sites (Figure 1), shortly prior to or following solute tracer experiments to minimize interference to both porewater samples and BTCs while ensuring similar conditions were present. Porewater samples were collected at 10 and $20 \mathrm{~cm}$ depth from multilevel mini-piezometers (Rivett et al., 2008; Krause et al., 2013), with sites 1 and 2 containing four multilevel mini-piezometers and site 3 containing seven multilevel mini-piezometers (Figure 1B). Sampling locations were chosen across bedforms so that a range of upwelling and downwelling sites were included in the dataset, resulting in vertical hydraulic gradients that were positive and negative ( -0.24 to 0.28 , Supplementary Table 1$)$. Vertical hydraulic gradients varied with discharge between seasons resulting in some measurement locations switching from upwelling to downwelling sites across seasons. Water samples were filtered through 0.45 then $0.22 \mu \mathrm{m}$ Nylon syringe filters (Thames Resteck, UK) into sterile centrifuge tubes and subsequently frozen until analysis.

Greenhouse gas samples were produced in the field from porewater samples using the headspace equilibrium method (McAuliffe, 1971). A headspace of $14 \mathrm{ml}$ ultrapure helium was introduced to a syringe containing $7 \mathrm{ml}$ of porewater sample and shaken for $2 \mathrm{~min}$ to equilibrate gases between the headspace and the water. The gas sample in the headspace was injected into a pre-evacuated exetainer and stored at room temperature, in the dark, until analysis. Further details can be found in ComerWarner et al. $(2019,2020)$.

\section{Laboratory Analysis}

Concentrations of $\mathrm{NH}_{4}^{+}, \mathrm{NO}_{3}^{-}$, and $\mathrm{NO}_{2}^{-}$in the porewater samples were determined using a continuous flow analyser (Skalar San++) and concentrations of $\mathrm{CO}_{2}, \mathrm{CH}_{4}$, and $\mathrm{N}_{2} \mathrm{O}$ were measured using two gas chromatographs (GCs) (Agilent 7890A). Henry's constant was then used to convert the concentration in the gas sample (hence the headspace) to the concentration in the porewater sample (Wilhelm et al., 1977; Hudson, 2004). Details on analysis, accuracy, precision, and limit of detection for the above analyses can be found in Comer-Warner et al. $(2019,2020)$. Concentrations across all piezometers and depths for each site and season were averaged to give a site- and season-dependent concentration for each chemical species.

\section{Statistical Analysis}

All statistical analyses were conducted using the R V 3.3 (R Development Core Team, 2011). Spearman's rank correlation coefficients were calculated to assess relationships between variables in the dataset (Harrell Miscellaneous package; Harrell 
TABLE 2 | Details of the hydrological metrics presented here, including descriptions and how they were calculated.

\begin{tabular}{|c|c|c|c|}
\hline Metric & Description & $\begin{array}{l}\text { Characteristic } \\
\text { represented }\end{array}$ & Reference \\
\hline$t_{\mathrm{ad}}$ & $\begin{array}{l}\text { The downstream advective time calculated from the time between the tracer injection and } \\
\text { the peak concentration }\end{array}$ & Advective transport & e.g., Haggerty, 2002 \\
\hline$t_{99}$ & The time from injection at which $99 \%$ of the recovered solute mass was observed & & $\begin{array}{l}\text { e.g., Mason et al., 2012; } \\
\text { Ward et al., } 2013 a\end{array}$ \\
\hline$t_{w}$ & $\begin{array}{l}\text { The window of detection representing the maximum tracer recovery time calculated from } \\
\text { the time between the first arrival of tracer (when tracer was first detected) and t99 }\end{array}$ & $\begin{array}{l}\text { Dispersion and } \\
\text { transient storage }\end{array}$ & $\begin{array}{l}\text { e.g., Mason et al., 2012; } \\
\text { Ward et al., } 2013 a\end{array}$ \\
\hline$M_{1}$ & $\begin{array}{l}\text { The first temporal moment which is an estimate of mean arrival time calculated from the } \\
\text { normalized BTC }\end{array}$ & Advective transport & e.g., Schmadel et al., 2016 \\
\hline$t_{w, n o r m}$ & The normalized window of detection calculated by dividing $t_{w}$ by $t_{a d}$ & $\begin{array}{l}\text { Dispersion and } \\
\text { transient storage }\end{array}$ & $\begin{array}{l}\text { e.g., Gooseff et al., 2007; } \\
\text { Ward et al., } 2013 a\end{array}$ \\
\hline TSI & $\begin{array}{l}\text { The transient storage index representing the amount of tailing in a BTC calculated from the } \\
\text { time between } t_{a d} \text { and } \text { tg9 }_{9}\end{array}$ & $\begin{array}{l}\text { Dispersion and } \\
\text { transient storage }\end{array}$ & e.g., Mason et al., 2012 \\
\hline$T S I_{\text {norm }}$ & The normalized transient storage index calculated by dividing TSI by $t_{a d}$ & $\begin{array}{l}\text { Dispersion and } \\
\text { transient storage }\end{array}$ & $\begin{array}{l}\text { e.g., Gooseff et al., 2007; } \\
\text { Schmadel et al., } 2016\end{array}$ \\
\hline CV & $\begin{array}{l}\text { The coefficient of variance representing the rate of symmetrical spreading } \\
\text { normalized by mean travel time calculated from the second central moment }\end{array}$ & $\begin{array}{l}\text { Dispersion and } \\
\text { transient storage }\end{array}$ & Schmadel et al., 2016 \\
\hline$\gamma$ & $\begin{array}{l}\text { The skewness representing the extent of late-time tailing normalized by } \\
\text { symmetrical spreading calculated from the second and third central moments }\end{array}$ & $\begin{array}{l}\text { Dispersion and } \\
\text { transient storage }\end{array}$ & Schmadel et al., 2016 \\
\hline$\Delta M_{1}$ & The change in $M_{1}$ between the upstream and downstream sites of a reach & Advective transport & Schmadel et al., 2016 \\
\hline$\Delta t_{a d}$ & The change in $t_{a d}$ between the upstream and downstream sites of a reach & Advective transport & Schmadel et al., 2016 \\
\hline$\Delta t_{w}$ & The change in $\Delta t_{w}$ between the upstream and downstream sites of a reach & $\begin{array}{l}\text { Dispersion and } \\
\text { transient storage }\end{array}$ & Schmadel et al., 2016 \\
\hline$\Delta t_{w, n o r m}$ & The change in $t_{w, n o r m}$ between the upstream and downstream sites of a reach & $\begin{array}{l}\text { Dispersion and } \\
\text { transient storage }\end{array}$ & Schmadel et al., 2016 \\
\hline$\Delta T S I$ & The change in TS/ between the upstream and downstream sites of a reach & $\begin{array}{l}\text { Dispersion and } \\
\text { transient storage }\end{array}$ & Schmadel et al., 2016 \\
\hline$\Delta T S I_{\text {norm }}$ & The change in $\mathrm{TSI}_{\text {norm }}$ between the upstream and downstream sites of a reach & $\begin{array}{l}\text { Dispersion and } \\
\text { transient storage }\end{array}$ & Schmadel et al., 2016 \\
\hline$Q_{M}$ & $\begin{array}{l}\text { The mean discharge determined from the stream level measured at the downstream } \\
\text { continuous monitoring site }(D) \text { and a stage-discharge relationship }\end{array}$ & & Blaen et al., 2017a \\
\hline Mrec & The recovered tracer mass determined for each BTC from $Q_{M}$ & & Schmadel et al., 2016 \\
\hline Mloss & $\begin{array}{l}\text { The mass of tracer lost determined for each BTC calculated from the difference between } \\
M_{r e c} \text { and mass injected, divided by the mass injected }\end{array}$ & Long-term storage & Schmadel et al., 2016 \\
\hline$\Delta M_{\text {loss }}$ & The change in $M_{\text {loss }}$ between the upstream and downstream sites of a reach & Long-term storage & Schmadel et al., 2016 \\
\hline
\end{tabular}

The hydrological metrics used to investigate relationships with streambed chemistry are shown in bold.

and Dupont, 2020), due to the large number of comparisons made $p$-values were controlled for Type I errors using the False Discovery Rate method (Benjamini and Hochberg, 1995). The spearman test was preferred to a pearson test as this is non-parametric and allows non-linear relationships to also be explored. The exploration of non-linear relationships is crucial as the relationship between hydrology and streambed chemistry is not necessarily expected to be linear. A principal component analysis was performed using the Rattle GUI R software and package to further explore how variables related to each other. Prior to the ordination data were log-transformed, centered around their means, and values standardized to the standard deviation of the dataset (i.e., converted to Z-scores). To assess differences in streambed chemistry between study reaches and sample dates a MANOVA (Adonis function-Vegan package; Oksanen et al., 2020) was conducted. The MANOVA method partitions distance (in this case Euclidean distance) among explanatory variables and uses a permutation procedure (999 permutations) based on pseudo- $F$ ratios.

\section{RESULTS}

\section{Comparisons of Hydrological Metrics and Streambed Chemistry}

The focus of this study was the relationships between hydrology and streambed chemistry, therefore, spatial and temporal variability of hydrological metrics, resazurin-resorufin turnover, and streambed chemistry are shown in Figure $\mathbf{2}$ and Supplementary Figure 5, but are not considered in detail here. $\mathrm{CO}_{2}, \mathrm{CH}_{4}$, and $\mathrm{NH}_{4}^{+}$concentrations were generally highest in the sand-dominated sites, whereas $\mathrm{NO}_{3}^{-}, \mathrm{NO}_{2}^{-}$, and $\mathrm{N}_{2} \mathrm{O}$ concentrations were generally highest in the gravel-dominated site (Table 3). Seasonal variations were low with no significant 


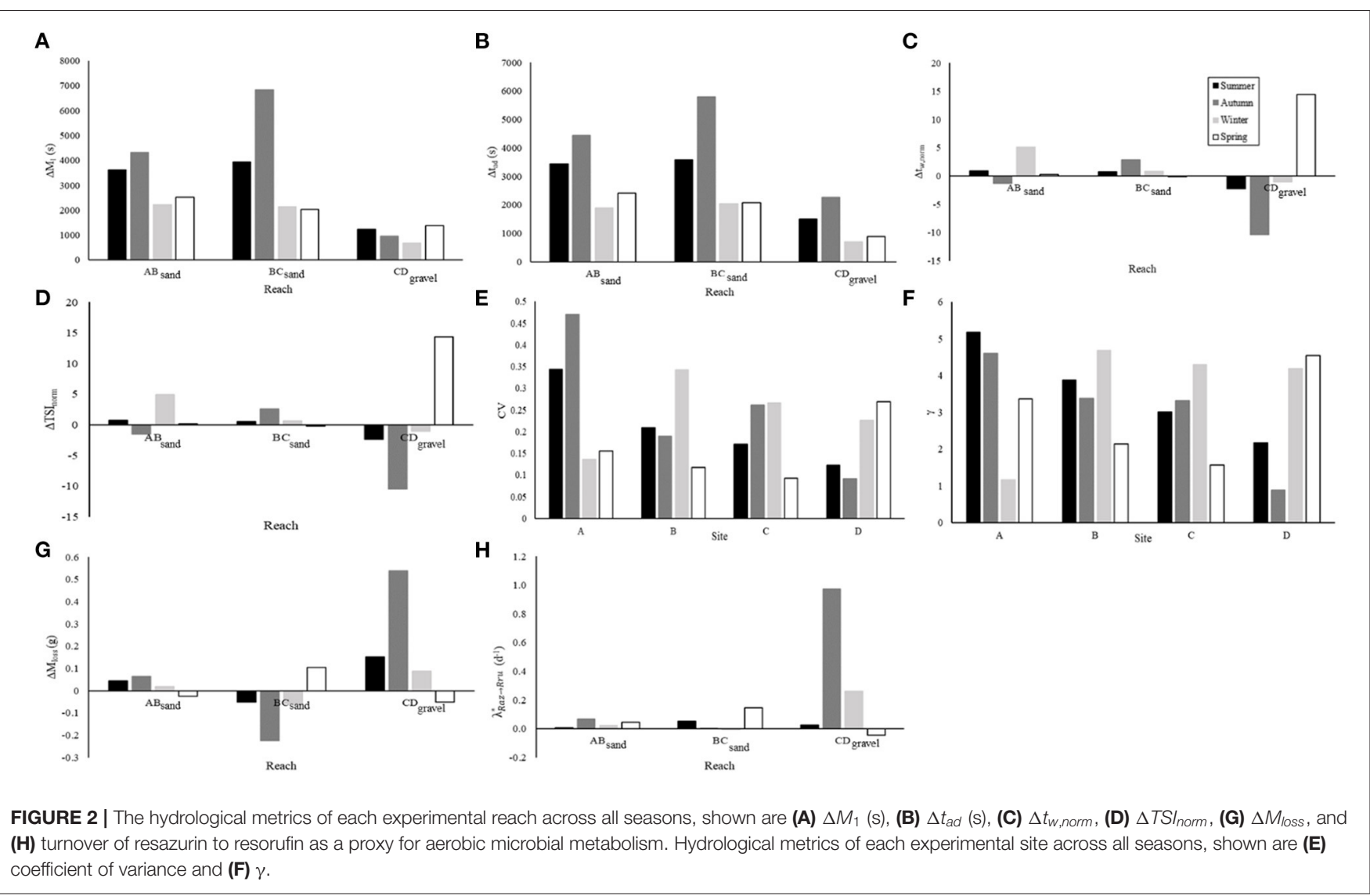

differences observed with respect to $\mathrm{CO}_{2}$ and $\mathrm{NO}_{2}^{-}$, whereas, $\mathrm{NH}_{4}^{+}, \mathrm{N}_{2} \mathrm{O}$, and $\mathrm{CH}_{4}$ concentrations were highest in Autumn and $\mathrm{NO}_{3}^{-}$concentrations were highest in Winter (Table 3). A more detailed interpretation of the streambed chemistry data is presented in Comer-Warner et al. $(2019,2020)$.

$\mathrm{CO}_{2}, \mathrm{CH}_{4}$, and $\mathrm{NH}_{4}^{+}$showed a positive correlation with each other $(r>0.66$, Figure 3 and Supplementary Figure 6), which was significant between $\mathrm{CO}_{2}$ and $\mathrm{CH}_{4}$, and $\mathrm{CH}_{4}$ and $\mathrm{NH}_{4}^{+}$(adjusted $p$-values of $<0.01$ and 0.01 , respectively, Supplementary Figure 6). $\mathrm{CO}_{2}, \mathrm{CH}_{4}$, and $\mathrm{NH}_{4}^{+}$were negatively correlated with $\mathrm{NO}_{3}^{-}, \mathrm{NO}_{2}^{-}$, and $\mathrm{N}_{2} \mathrm{O}$ ( $r$ between -0.36 and -0.86 , Figure 3 and Supplementary Figure 6). These negative correlations were significant (adjusted $p$-value $<$ 0.04, Supplementary Figure 6) except those between $\mathrm{NH}_{4}^{+}$ and $\mathrm{N}_{2} \mathrm{O}$ and $\mathrm{NH}_{4}^{+}$and $\mathrm{NO}_{3}^{-}$(adjusted $p$-value $>0.05$, Supplementary Figure 6). $\mathrm{NO}_{3}^{-}$showed a positive correlation with $\mathrm{NO}_{2}^{-}$and $\mathrm{N}_{2} \mathrm{O}$, which was only significant with $\mathrm{N}_{2} \mathrm{O}(r$ $=0.48$ and 0.78 , adjusted $p$-value $=0.23$ and 0.01 , respectively, Figure 3 and Supplementary Figure 6). $\mathrm{NO}_{2}^{-}$and $\mathrm{N}_{2} \mathrm{O}$ showed an insignificant, positive correlation with each other $(r=0.66$, adjusted $p$-value $=0.05$, Figure 3 and Supplementary Figure 6).

Streambed $\mathrm{CO}_{2}, \mathrm{CH}_{4}$, and $\mathrm{NH}_{4}^{+}$showed a positive correlation with $\Delta M_{1}$ and $\Delta t_{a d}$, which was significant except between $\mathrm{CO}_{2}$ and $\Delta t_{a d}(r>0.64$, adjusted $p$-values between $<0.01$ and 0.04 , Figure 3 and Supplementary Figures 7-9). Streambed $\mathrm{CO}_{2}$, $\mathrm{CH}_{4}$, and $\mathrm{NH}_{4}^{+}$were negatively related to $\Delta M_{\text {loss }}$ ( $r$ between -0.42 and -0.68 , Figure 3 and Supplementary Figures 7-9), which was only significant between $\mathrm{CO}_{2}$ and $\Delta M_{\text {loss }}$ (adjusted $p$-value $=0.04$, Supplementary Figures 7-9). Streambed $\mathrm{CO}_{2}$, $\mathrm{CH}_{4}$, and $\mathrm{NH}_{4}^{+}$were not significantly correlated with $\Delta t_{w, n o r m}$, $\Delta T S I_{\text {norm }}, C V$, or $\gamma(r$ between -0.07 and 0.41 , adjusted $p$-values $>0.05$, Figure 3 and Supplementary Figures 7-9).

Streambed $\mathrm{NO}_{3}^{-}, \mathrm{NO}_{2}^{-}$, and $\mathrm{N}_{2} \mathrm{O}$ showed a negative correlation with $\Delta M_{1}$ and $\Delta t_{a d}$ ( $r$ between -0.53 and -0.81 , Figure 3 and Supplementary Figures 10-12), which was only significant for $\mathrm{N}_{2} \mathrm{O}$ (adjusted $p$-value $<0.02$, Supplementary Figures 10-12). Streambed $\mathrm{NO}_{3}^{-}, \mathrm{NO}_{2}^{-}$, and $\mathrm{N}_{2} \mathrm{O}$ were not significantly correlated with $\Delta t_{w, n o r m}$, $\Delta T S I_{\text {norm }}, \mathrm{CV}$ or $\gamma(r$ between 0.02 and -0.38 , adjusted $p$ values $>0.05$, Figure 3 and Supplementary Figures 10-12). $\mathrm{NO}_{3}^{-}, \mathrm{NO}_{2}^{-}$, and $\mathrm{N}_{2} \mathrm{O}$ were positively related to $\Delta M_{\text {loss }}(r$ $=0.36-0.48$, Figure 3 and Supplementary Figures 10-12), however these were not significant (adjusted $p$-values $>0.05$ and Supplementary Figures 10-12). There was no significant correlation between $\lambda_{R a z \rightarrow R r u}^{*}$ and any of the chemical species (adjusted $p$-values $>0.05$, and Supplementary Figures 7-12).

Principal components 1 and 2 described $\sim 80 \%$ of the variation in the measured parameters. The relationships between the variables were consistent with the results of the correlation analysis. The distribution of reach observations in PCA space (components 1 and 2) indicated differences between reaches; in particular, $\mathrm{CD}_{\text {gravel }}$ was separated from $\mathrm{AB}_{\text {sand }}$ and $\mathrm{BC}_{\text {sand }}$ (Figure 4A). However, observations overlapped between seasons, therefore, the structure of the data is spatially and not seasonally 
TABLE 3 | The mean and one standard deviation of streambed nutrient and greenhouse gas concentrations across sites and seasons.

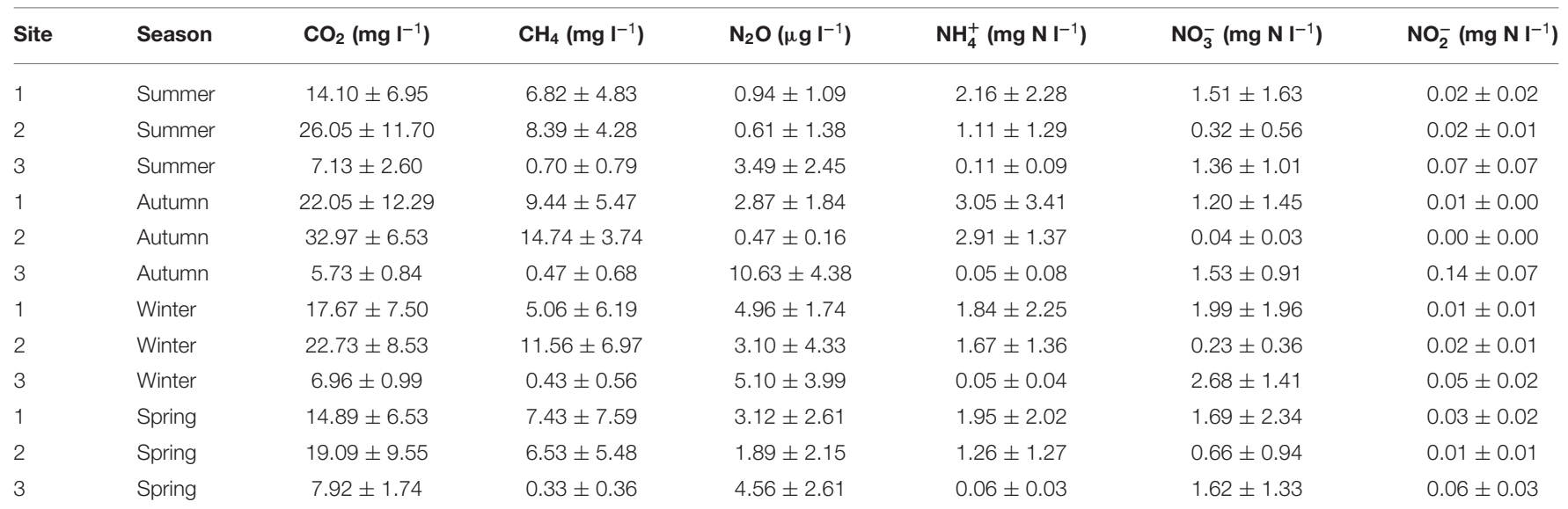

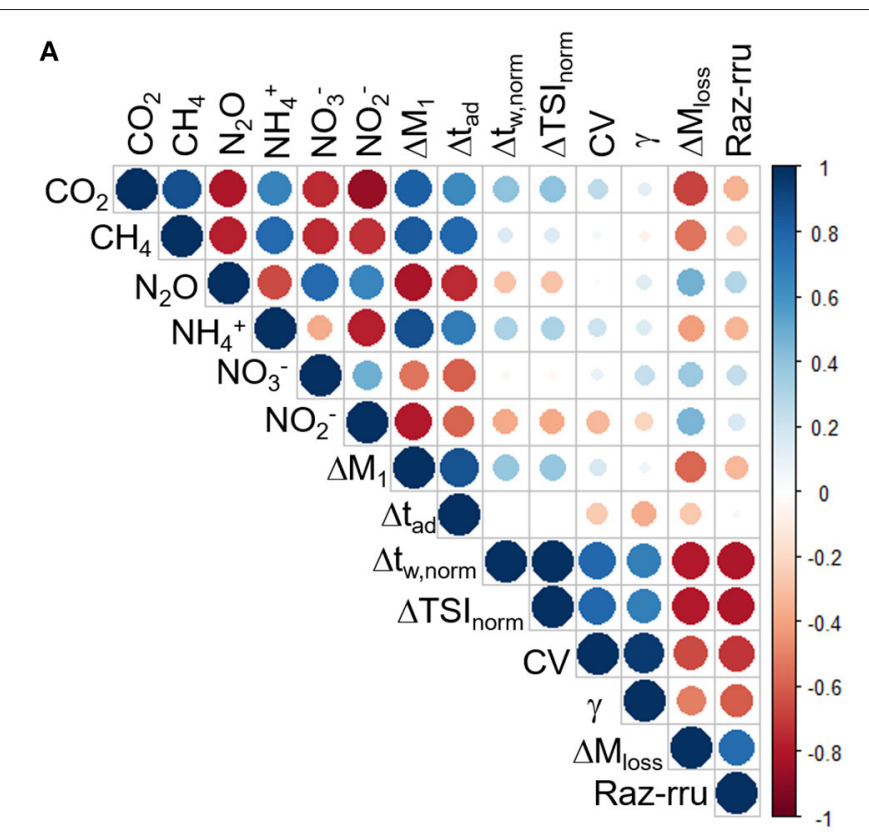

B

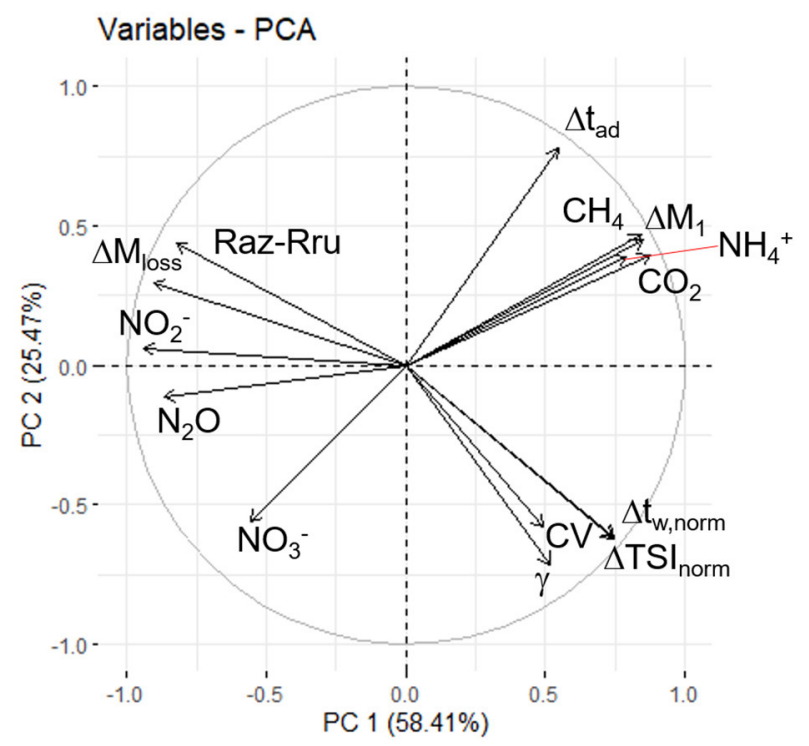

FIGURE 3 | (A) A plot of the spearman rank correlation coefficients for all hydrological and chemical parameters. The correlation is indicated by color and circle size where blue indicates a positive correlation and red indicates a negative correlation, with the gradient of color indicating the strength of the correlation. The strength of the correlation is further indicated by circle size. Plots of the data for each of the correlations, including whether they are significant, are presented in Supplementary Figures 6-12. (B) The contribution of variables to principal component 1 and principal component 2 vectors.

structured (Figure 4B). Significant differences in streambed chemistry were observed between sites (MANOVA; $F=3.77 ; P$ $=0.01$ ) but not sample dates (MANOVA; $F=1.74 ; P>0.05)$. A pairwise comparison highlighted that $\mathrm{CD}_{\text {gravel }}$ was significantly different to $\mathrm{AB}_{\text {sand }}(F=4.45 ; P<0.05)$ and $\mathrm{BC}_{\text {sand }}(F=4.99$; $P<0.05)$, while the sand reaches had no significant differences with regards to streambed chemistry.

\section{DISCUSSION}

Streambed chemical concentrations in the agricultural, lowland stream studied here were related, in some cases, to advective transport $\left(\Delta M_{1}\right.$ and $\left.\Delta t_{a d}\right)$ and long-term storage $\left(\Delta M_{\text {loss }}\right)$ but not dispersion and transient storage $\left(\Delta t_{w, n o r m}, \Delta T S I_{n o r m}, C V\right.$, or $\gamma$ ). The direction and significance of the relationships varied between chemical species with $\mathrm{CO}_{2}, \mathrm{CH}_{4}$, and $\mathrm{NH}_{4}^{+}$positively related to advective transport time and $\mathrm{NO}_{3}^{-}, \mathrm{NO}_{2}^{-}$, and $\mathrm{N}_{2} \mathrm{O}$ negatively related. Hence, the relationship between reach-scale hydrology, and streambed chemistry may not be as strong as previously thought, with transient storage having less influence than advective transport time through a stream reach.

The lack of a relationship between $\mathrm{CO}_{2}$ concentration and resazurin-resorufin turnover was unexpected given the wide use of resazurin as a proxy for aerobic respiration (Haggerty et al., 2009; González-pinzón et al., 2012; Knapp et al., 2018). Here, $\mathrm{CO}_{2}$ concentration was measured rather than production or 


\section{A}

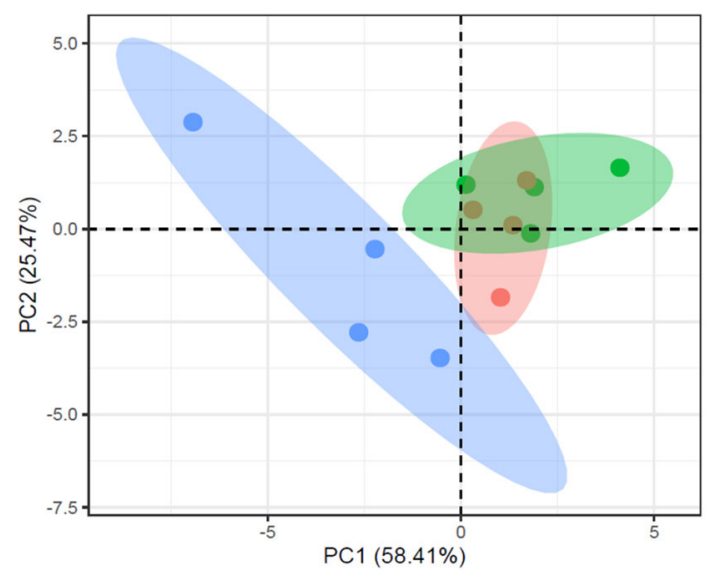

B

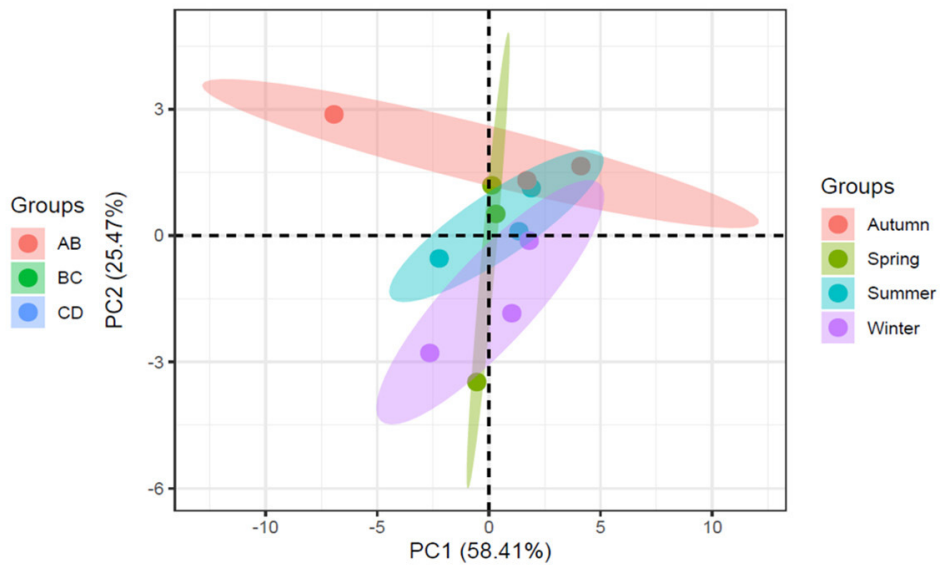

FIGURE 4 | The projection of (A) reach and (B) seasonal observations on principal component 1 and principal component 2.

concentration change, which may explain the lack of relationship observed. Additionally, sediment $\mathrm{CO}_{2}$ concentration and instream respiration may not be closely related and resazurinresorufin may only serve as a proxy for in-stream respiration, not streambed respiration, if hyporheic exchange is low. Further investigation is required to explore the causes of the lack of relationship as there could be wider implications for the use of resazurin to quantify metabolically active transient storage and reach-scale aerobic respiration, especially because hyporheic respiration can account for a high proportion of total stream respiration (Battin et al., 2003a,b). The resazurin-resorufin system, therefore, may not accurately quantify hyporheic zone respiration, especially with short windows of detection resulting from the use of instantaneous tracer injections. Significant limitations in the ability of resazurin-to-resorufin transformation to reproduce respiration rates calculated from diel-oxygen profiles have also been observed (Knapp and Cirpka, 2018), which provides further evidence for caution when using the resazurin-resorufin tracer system.

\section{Comparisons of Hydrological Metrics and Streambed Chemistry}

The positive correlation between $\mathrm{CO}_{2}, \mathrm{CH}_{4}$, and $\mathrm{NH}_{4}^{+}$indicates that concentrations of these chemical species were high within the same areas of the streambed, likely due to the breakdown of organic matter and anaerobic conditions within the streambed (Baker et al., 2000; Duff and Triska, 2000). These conditions decrease the rate of nitrification, therefore, less $\mathrm{NH}_{4}^{+}$is converted to $\mathrm{NO}_{3}^{-}$and conditions are suitable for denitrification to reduce $\mathrm{NO}_{3}^{-}$, explaining why the negative correlation between these two nutrients was not significant. The positive correlation between $\mathrm{NO}_{3}^{-}, \mathrm{NO}_{2}^{-}$, and $\mathrm{N}_{2} \mathrm{O}$ likely reflects their involvement in similar reaction processes e.g., nitrification and denitrification (Kendall, 1998; Duff and Triska, 2000; Trimmer et al., 2006). A significant correlation was expected but was only observed between $\mathrm{NO}_{3}^{-}$ and $\mathrm{N}_{2} \mathrm{O}$.
Findings here support previous relationships between GHG fluxes and nutrients that were significant and positive between $\mathrm{CO}_{2}$ and $\mathrm{NH}_{4}^{+}, \mathrm{CH}_{4}$ and $\mathrm{NH}_{4}^{+}$, and $\mathrm{N}_{2} \mathrm{O}$ and $\mathrm{NO}_{2}^{-}$, and significant and negative between $\mathrm{CO}_{2}$ and $\mathrm{NO}_{3}^{-}, \mathrm{CH}_{4}$ and $\mathrm{NO}_{3}^{-}$, and $\mathrm{N}_{2} \mathrm{O}$ and $\mathrm{NH}_{4}^{+}$(Vidon and Serchan, 2016b), indicating nutrient controls on streambed GHGs. These correlations can also be explained by flowpath length or reaction times with higher residence times found at longer flowpath lengths and times typically resulting in increased concentrations of $\mathrm{CO}_{2}, \mathrm{CH}_{4}$, and $\mathrm{NH}_{4}^{+}$and decreased $\mathrm{NO}_{3}^{-}$concentrations.

Higher concentrations of $\mathrm{CO}_{2}, \mathrm{CH}_{4}$, and $\mathrm{NH}_{4}^{+}$, at longer advective transport times is likely due to more time for biogeochemical reactions to occur with these species accumulating in the streambed (Pinay et al., 2009; Zarnetske et al., 2011; Boodoo et al., 2017). Conversely, lower concentrations of $\mathrm{NO}_{3}^{-}, \mathrm{NO}_{2}^{-}$, and $\mathrm{N}_{2} \mathrm{O}$, at longer advective transport times illustrates the conversion of these products to other intermediate or final products due to increased time for biogeochemical reactions to occur (Pinay et al., 2009; Zarnetske et al., 2011; Marzadri et al., 2012; Quick et al., 2016; Hampton et al., 2020). Previous work has shown streambed GHG concentrations are controlled by river hydrological stage and hyporheic exchange (Hampton et al., 2020; Villa et al., 2020). Contrasting influence of flowpaths and downwelling/upwelling zones indicate that $\mathrm{CH}_{4}$ increases along flowpaths and is higher in anoxic, upwelling zones whereas $\mathrm{N}_{2} \mathrm{O}$ has been found to vary with flowpath or remain unchanged along flowpaths (Hlaváčová et al., 2005; Reeder et al., 2018).

The negative relationship observed between $\mathrm{NO}_{3}^{-}$and transport time may reflect the dominance of nitrification over denitrification at shorter residence times that has previously been documented (Zarnetske et al., 2011; Marzadri et al., 2012), although this was not significant. These results may support findings that hyporheic zone solute transport is driven by advection and increased uptake of $\mathrm{N}$ occurs at higher travel times (Bukaveckas, 2007; Marzadri et al., 2012; Vidon and Serchan, 2016a), although a direct comparison is not possible 
as concentrations not reaction rates were measured here and streambed residence times were not measured. Conversely, no significant relationship between advective transport and ecosystem respiration is also possible (Blaen et al., 2018). A non-linear relationship between $\mathrm{NO}_{3}^{-}, \mathrm{NO}_{2}^{-}$, and $\mathrm{N}_{2} \mathrm{O}$ and advective transport time was expected as these chemical species are produced and then consumed with increasing residence times (Burgin et al., 2013; Marzadri et al., 2014; Quick et al., 2016; Hampton et al., 2020).

A significant relationship between the chemical species and dispersion and transient storage was not observed. As streambed chemical species were measured these were expected to be directly linked to dispersion and transient storage as exchange of surface water into the streambed increases biogeochemical reactivity and residence time affects $\mathrm{C}$ and $\mathrm{N}$ concentrations (Hall et al., 2002; McClain et al., 2003; Thomas et al., 2003; Faulkner and Campana, 2007; Lautz and Fanelli, 2008). The relationship between dispersion and transient storage, and nitrogen and carbon cycling is complex with varying relationships previously observed. Dispersion and transient storage have been found to both control and have no effect on $\mathrm{N}$ and $\mathrm{C}$ cycling (Jones et al., 1995; Hall et al., 2002; Bernot et al., 2010; Baker et al., 2012). The varying relationship may be due to dispersion exerting only secondary control on solute transport in the hyporheic zone (Marzadri et al., 2012). In some cases $\Delta M_{\text {loss }}$ was negative and may result from fluorometer locations, i.e., stream reaches, intersecting longer flowpaths where tracer mass enters the streambed in one reach and is returned to the surface flow in the next reach.

Dispersion and transient storage are affected by both surface and sub-surface processes. The metrics calculated here may have been dominated by surface processes or reflect storage processes occurring at short timescales resulting in a lack of relationship (Harvey and Bencala, 1993; Ward et al., 2013b). Further evidence is provided by the significant correlation between $\mathrm{CO}_{2}$ and longterm storage, which may indicate that flow paths with relatively high residence times control streambed chemistry rather than flow paths with short residence times. Further influence on these relationships are indicated by the spatial and temporal groupings shown in Figure 4. The sand-dominated reaches overlap and are separated from the gravel-dominated reach; therefore, the sediment type appears to have a large control on the streambed chemistry, independent of the hydrology. It is crucial, therefore, to consider the effects of sediment type on hydrologic metrics when investigating relationships between streambed chemistry and hydrology. Differences in carbon and nitrogen cycling between the sand-dominated and gravel-dominated reaches have been observed at this site (Comer-Warner et al., 2019, 2020). These studies found the sand-dominated sediments were characterized by higher rates of microbial activity and denitrification with lower concentrations of nitrate, nitrite and lower rates of recalcitrant $\mathrm{C}$ uptake than the gravel-dominated sediments. Denitrification was also more complete in the sanddominated sediments, these characteristics resulted in sanddominated sediments having higher concentrations of $\mathrm{CO}_{2}, \mathrm{CH}_{4}$, and $\mathrm{CH}_{4}: \mathrm{CO}_{2}$ ratios, and lower concentrations of $\mathrm{N}_{2} \mathrm{O}$ than the gravel-dominated sediments (Comer-Warner et al., 2019,
2020). Seasonally there was no significant difference in streambed chemistry, while there were large variations in discharge and hydrological metrics, providing further evidence for additional controlling factors on streambed chemistry. This may explain some of the unexpected observations discussed above.

\section{Methodological Considerations}

In this study point-scale streambed chemistry measurements were compared to reach-scale hydrological metrics and aerobic respiration. We acknowledge that there is a discrepancy in scale in the dataset but believe that relating point and reach-scale observations is the next challenge to understanding controls on biogeochemical cycling. To reduce some of the issues arising from differences in scale we sampled from four to seven piezometers at each streambed sampling site. The piezometers were located through bedforms with upwelling and downwelling locations sampled, to prevent a point measurement representing one extreme of a flow path (Supplementary Table 1). Future studies could improve this design by sampling multiple bedforms within each experimental reach and measuring streambed hydrology concurrently with surface hydrology. This would also aid in controlling for local factors influencing chemical concentrations independent of hydrology, such as sorption of $\mathrm{NH}_{4}^{+}$onto clay sediments.

\section{CONCLUSIONS}

Advective transport time was related to streambed biogeochemical concentrations, with higher concentrations of $\mathrm{CO}_{2}, \mathrm{CH}_{4}$, and $\mathrm{NH}_{4}^{+}$and lower concentrations of $\mathrm{NO}_{3}^{-}$, $\mathrm{NO}_{2}^{-}$, and $\mathrm{N}_{2} \mathrm{O}$ at longer advective transport times. Long-term storage also exhibited a significant, positive relationship with $\mathrm{CO}_{2}$. The effect of advective transport time and long-term storage was dependent on chemical species. $\mathrm{NH}_{4}^{+}, \mathrm{CO}_{2}$, and $\mathrm{CH}_{4}$ exhibited positive relationships and $\mathrm{NO}_{3}^{-}, \mathrm{NO}_{2}^{-}$, and $\mathrm{N}_{2} \mathrm{O}$ exhibiting negative relationships with advective transport time. The opposite pattern was observed with long-term storage. Dispersion and transient storage did not indicate significant controls on any of the measured chemical species.

These findings contribute to community knowledge of the hydrological drivers of streambed GHGs. They indicate that further to controls of hyporheic residence times previously determined, processes affecting advective transport and not dispersion or transient storage may have the greatest effect on streambed nutrient and GHG concentrations. These hydrological drivers interrelate with other environmental parameters, which are also influenced by local hydrology. Sediment type, substrate availability, and season have also been found to influence streambed chemistry at this site (Comer-Warner et al., 2019, 2020). Further understanding of the effects of distal drivers (e.g., discharge) on hydrological variables and therefore, streambed chemistry should enable predictions of hyporheic nutrient cycling and GHG emissions aiding in effective pollution and climate remediation. Improved understanding may also allow morphological restoration to effectively target nutrient pollution and GHG emissions, which will aid in effective pollution and climate remediation. 
This improved understanding may allow chemical species to be effectively targeted by morphological restoration, which will aid in effective pollution and climate remediation.

Further investigation into the effects of hydrological metrics on $\mathrm{C}$ and $\mathrm{N}$ cycling is crucial to improve understanding of global $\mathrm{C}$ and $\mathrm{N}$ budgets and effects of global change on streams and rivers. Here, streambed concentrations of GHGs were measured and future work should focus on the relationships between hydrological metrics, and reaction rates and fluxes to provide further insight into links between hydrology and streambed chemistry. This, combined with the work presented here, will enable the effects of short-term and long-term hydrological variation, e.g., from storm events or climate change, on GHG dynamics to be better understood. Previous work shows that streambed $\mathrm{N}_{2} \mathrm{O}$ is highest at intermediate residence times (Zarnetske et al., 2011; Quick et al., 2016), however, previously streambed dynamics have not been linked directly with advection, dispersion or transient storage. Installing benthic chambers to measure sediment-water fluxes of GHG and measuring concentration over time will help to further constrain these processes. Improved understanding of the relationships between hydrogeomorphology and advection, dispersion and transient storage will enable conditions advantageous for the reduction of pollution and GHG emissions to be determined. Including streambed GHG emissions and separated transient storage (surface and subsurface) in further investigations would be beneficial (Briggs et al., 2009; Krause et al., 2011). Additionally, considering legacy effects of hydrologic conditions prior to tracer experiments, which may affect streambed chemistry for longer periods and therefore, during tracer experiments where hydrology may have changed, is crucial to further our understanding.

\section{DATA AVAILABILITY STATEMENT}

The datasets generated for this study can be found in online repositories. The names of the repository/repositories

\section{REFERENCES}

Anderson, B., Bartlett, K., Frolking, S., Hayhoe, K., Jenkins, J., and Salas, W. A. (2010). Methane and Nitrous Oxide Emissions from Natural Sources. Washington, DC: Office of Atmospheric Programs, US EPA, EPA 430-R-10001.

Baker, D. W., Bledsoe, B. P., and Price, J. M. (2012). Stream nitrate uptake and transient storage over a gradient of geomorphic complexity, north-central Colorado, USA. Hydrol. Process. 26, 3241-3252. doi: 10.1002/hyp. 8385

Baker, M. A., Dahm, C. N., and Valett, H. M. (2000). "Anoxia, anaerobic metabolism, and biogeochemistry of the stream-water-groundwater interface," in Streams and Ground Waters, 2nd Edn., eds J. B. Jones and P. J. Mulholland, (San Diego, CA: Elsevier), 259-283. doi: 10.1016/B978-0-12-389845-6. 50012-0

Battin, T J., Kaplan, L. A., Newbold, J. D., and Hendricks, S. P. (2003a). A mixing model analysis of stream solute dynamics and the contribution of a hyporheic zone to ecosystemfunction. Freshwater Biol.48, 995-1014. doi: 10.1046/j.1365-2427.2003.01062.x and accession number(s) can be found below: NERC's Environmental Information Data Centre, doi: $\quad 10.5285 / 00601260-285 e-4 f f a-b 381-340 b 51 a 7 e c 50$ and doi: 10.5285/5b34d963-d0f0-465e-b395-e955b89e1cd7.

\section{AUTHOR CONTRIBUTIONS}

SC-W, DG, and SK conceived of and planned the experiment. $\mathrm{SC}-\mathrm{W}, \mathrm{PB}, \mathrm{NB}$, and $\mathrm{AB}$ were involved in data acquisition. SC, $\mathrm{CL}$, and KK were involved in data analysis. SC-W wrote the manuscript and all other authors contributed to manuscript editing. DG and SK provided funding. All authors contributed to the article and approved the submitted version.

\section{FUNDING}

Funding was provided by NERC through a Central England NERC Training Alliance Studentship and grant NE/L004437/1, with additional funding provided by the European Union through the H2020-MSCA-RISE-2016 project 734317.

\section{ACKNOWLEDGMENTS}

DG published with the permission of the Director of the British Geological Survey (NERC). The authors would like to thank the Birmingham Institute of Forest Research for providing support and access to the study site and Prof. Adam Ward and Jase Hixson for allowing us to borrow their fluorometers and for calculating temperature and turbidity corrections for these.

\section{SUPPLEMENTARY MATERIAL}

The Supplementary Material for this article can be found online at: https://www.frontiersin.org/articles/10.3389/frwa. 2021.668183/full\#supplementary-material

Battin, T. J., Kaplan, L. A., Newbold, J. D., and Hansen, C. M. E. (2003b) Contributions of microbial biofilms to ecosystem processes in stream mesocosms. Nature 426, 439-442. doi: 10.1038/nature02152

Beaulieu, J. J., Tank, J. L., Hamilton, S. K., Wollheim, W. M., Hall, R. O., Mulholland, P. J., et al. (2011). Nitrous oxide emission from denitrification in stream and river networks. Proc. Natl. Acad. Sci. U.S.A. 108, 214-219. doi: $10.1073 /$ pnas. 1011464108

Bencala, K. E., Gooseff, M. N., and Kimball, B. A. (2011). Rethinking hyporheic flow and transient storage to advance understanding of stream-catchment connections. Water Resour. Res. 47:W00H03. doi: 10.1029/2010WR010066

Bencala, K. E., and Walters, R. A. (1983). Simulation of solute transport in a mountain pool-and-riffle stream: a transient storage model. Water Resour. Res. $19,718-724$.

Benjamini, Y., and Hochberg, Y. (1995). Controlling the false discovery rate: a practical and powerful approach to multiple testing. J. R. Stat. Soc. 57, 289-300.

Bernot, M. J., Sobota, D. J., Hall, Jr.., R. O., Mulholland, P. J., Dodds, W. K., et al. (2010). Inter-regional comparison of land-use effects on stream metabolism. Freshwater Biol. 55, 1874-1890. doi: 10.1111/j.1365-2427.2010.02422.x 
Blaen, P.J., Kurz, M. J., Drummond, J. D., Knapp, J. L. A., Mendoza-Lera, C., Schmadel, N. M., et al. (2018). Woody debris is related to reach-scale hotspots of lowland stream ecosystem respiration under baseflow conditions. Ecohydrology 11:e1952. doi: 10.1002/eco.1952

Blaen, P. J., Brekenfeld, N., Comer-Warner, S., and Krause, S. (2017a). Multitracer field fluorometry: accounting for temperature and turbidity variability during stream tracer tests. Water Resour. Res. 53, 9118-9126. doi: 10.1002/2017WR020815

Blaen, P. J., Khamis, K., Lloyd, C., Comer-Warner, S., Ciocca, F., Thomas, R. M., et al. (2017b). High-frequency monitoring of catchment nutrient exports reveals highly variable storm event responses and dynamic source zone activation. J. Geophys. Res. Biogeosci. 122, 1-17. doi: 10.1002/2017JG003904

Boano, F., Demaria, A., Revelli, R., and Ridolfi, L. (2010). Biogeochemical zonation due to intrameander hyporheic flow. Water Resour. Res. 46:W02511. doi: 10.1029/2008WR007583

Boodoo, K. S., Trauth, N., Schmidt, C., Schelker, J., and Battin, T. J. (2017). Gravel bars are sites of increased $\mathrm{CO}_{2}$ outgassing in stream corridors. Sci. Rep. 7, 1-9. doi: 10.1038/s41598-017-14439-0

Boulton, A. J., Findlay, S., Marmonier, P., Stanley, E. H., and Valett, H. M. (1998). The functional significance of the hyporheic zone in streams and rivers. Annu. Rev. Ecol. Syst. 29, 59-81. doi: 10.1146/annurev.ecolsys.29.1.59

Briggs, M. A., Gooseff, M. N., Arp, C. D., and Baker, M. A. (2009). A method for estimating surface transient storage parameters for streams with concurrent hyporheic storage. Water Resour. Res. 45:W00D27. doi: 10.1029/2008WR006959

Brunke, M., and Gonser, T. (1997). The ecological significance of exchange processes between rivers and groundwater. Freshwater Biol. 37, 1-33. doi: 10.1046/j.1365-2427.1997.00143.x

Bukaveckas, P. A. (2007). Effects of channel restoration on water velocity, transient storage, and nutrient uptake in a channelized stream. Environ. Sci. Technol. 41, 1570-1576. doi: 10.1021/es061618x

Burgin, A. J., Lazar, J. G., Groffman, P. M., Gold, A. J., and Kellogg, D. Q. (2013). Balancing nitrogen retention ecosystem services and greenhouse gas disservices at the landscape scale. Ecol. Eng. 56, 26-35. doi: 10.1016/j.ecoleng.2012.05.003

Cai, S.-S., and Stark, J. D. (1997). Evaluation of five fluorescent dyes and triethyl phosphate as atmospheric tracers of agricultural sprays. J. Environ. Sci. Health B 32, 969-983.

Cole, J. J., Prairie, Y. T., Caraco, N. F., McDowell, W. H., Tranvik, L. J., Striegl, R. G., et al. (2007). Plumbing the global carbon cycle: integrating inland waters into the terrestrial carbon budget. Ecosystems 10, 172-185. doi: 10.1007/s10021-006-9013-8

Comer-Warner, S. A, Gooddy, D. C., Ullah, S., Glover, L., Percival, A., Kettridge, N., and Krause, S. (2019). Seasonal variability of sediment controls of carbon cycling in an agricultural stream. Sci. Total Environ. 688, 732-741. doi: 10.1016/j.scitotenv.2019.06.317

Comer-Warner, S. A., Gooddy, D. C., Ullah, S., Glover, L., Kettridge, N., Wexler, S. K., et al. (2020). Seasonal variability of sediment controls of nitrogen cycling in an agricultural stream. Biogeochemistry 148, 31-48. doi: $10.1007 /$ s10533-020-00644-z

Duff, J. H., and Triska, F. J. (2000). "Nitrogen biogeochemistry and surfacesubsurface exchange in streams," in Streams and Ground Waters, 2nd Edn. eds J. Jones and P. J. Mulholland (San Diego, CA: Elsevier Inc.), 197-220. doi: 10.1016/B978-0-12-389845-6.50009-0

Faulkner, B. R., and Campana, M. E. (2007). Compartmental model of nitrate retention in streams. Water Resour. Res. 43:W02406. doi: 10.1029/2006WR004920

Findlay, S. (1995). Importance of surface-subsurface exchange in stream ecosystems: the hyporheic zone. Limnol. Oceanogr. 40, 159-164. doi: 10.4319/lo.1995.40.1.0159

González-pinzón, R., Haggerty, R., and Argerich, A. (2014). Quantifying spatial differences in metabolism in headwater streams. Freshwater Sci. 33, 798-811. doi: $10.1086 / 677555$

González-pinzón, R., Haggerty, R., and Myrold, D. D. (2012). Measuring aerobic respiration in stream ecosystems using the resazurin-resorufin system. J. Geophys. Res. Biogeosci. 117, 1-10. doi: 10.1029/2012JG001965

Gooseff, M. N., Hall, R. O. Jr., and Tank, J. L. (2007). Relating transient storage to channel complexity in streams of varying land use in Jackson Hole, Wyoming. Water Resour. Res. 43:W01417. doi: 10.1029/2005WR004626
Gooseff, M. N., LaNier, J., Haggerty, R., and Kokkeler, K. (2005). Determining in-channel (dead zone) transient storage by comparing solute transport in a bedrock channel-alluvial channel sequence, Oregon. Water Resour. Res. 41, 1-7. doi: 10.1029/2004WR003513

Haggerty, R., Argerich, A., and Martí, E. (2008). Development of a “smart" tracer for the assessment of microbiological activity and sediment-water interaction in natural waters: the resazurin-resorufin system. Water Resour. Res. 46, 1-10. doi: 10.1029/2007WR006670

Haggerty, R., Martí, E., Argerich, A., Von Schiller, D., and Grimm, N. B. (2009). Resazurin as a "smart" tracer for quantifying metabolically active transient storage in stream ecosystems. J. Geophys. Res. Biogeosci. 114, 1-14. doi: 10.1029/2008JG000942

Haggerty, R., Wondzell, S. M., and Johnson, M. A. (2002). Power-law residence time distribution in the hyporheic zone of a 2nd-order mountain stream. Geophys. Res. Lett. 29, 1-4. doi: 10.1029/2002GL014743

Hall, R. O. Jr., Bernhardt, E. S., and Likens, G. E. (2002). Relating nutrient uptake with transient storage in forested mountain streams. Limnol. Oceanogr. 47, 255-265. doi: 10.4319/lo.2002.47.1.0255

Hampton, T. B., Zarnetske, J. P., Briggs, M. A., MahmoodPoor Dehkordy, F., Singha, K., Day-Lewis, F. D., et al. (2020). Experimental shifts of hydrologic residence time in a sandy urban stream sediment-water interface alter nitrate removal and nitrous oxide fluxes. Biogeochemistry 149, 195-219. doi: 10.1007/s10533-020-00674-7

Harrell, F. E. Jr., and Dupont, C. (2020). Hmisc: Harrell Miscellaneous. R package version 4.4-1. Available online at: https://CRAN.R-project.org/package=Hmisc

Harvey, J. W., and Bencala, K. E. (1993). The effect of streambed topography on surface-subsurface water exchange in mountain catchments. Water Resour. Res. $29,89-98$.

Harvey, J. W., Böhlke, J. K., Voytek, M., a., Scott, D., and Tobias, C. R. (2013). Hyporheic zone denitrification: controls on effective reaction depth and contribution to whole-stream mass balance. Water Resour. Res. 49, 6298-6316. doi: 10.1002/wrcr.20492

Harvey, J. W., and Wagner, B. J. (2000). "Quantifying hydrologic interactions between streams and their subsurface hyporheic zones," in Streams and Ground Waters, 2nd Edn., eds J. B. Jones and P. J. Mulholland (San Diego, CA: Elsevier Inc.), 3-44. doi: 10.1016/B978-012389845-6/50002-8

Harvey, J. W., Wagner, B. J., and Bencala, K. E. (1996). Evaluating the reliability of the stream tracer approach to characterize stream-subsurface water exchange. Water Resour. Res. 32, 2441-2451.

Hlaváčová, E., Rulík, M., and Cáp, L. (2005). Anaerobic microbial metabolism in hyporheic sediment of a gravel bar in a small lowland stream. River Res. Appl. 21, 1003-1011. doi: 10.1002/rra.866

Hudson, F. (2004). Sample Preparation and Calculations for Dissolved Gas Analysis in Water Samples Using a GC Headspace Equilibration Technique. Available online at: https://archive.epa.gov/region1/info/testmethods/web/pdf/ rsksop175v2.pdf (accessed March 2020).

Jin, L., Siegel, D. I., Lautz, L. K., and Otz, M. H. (2009). Transient storage and downstream solute transport in nested stream reaches affected by beaver dams. Hydrol. Process. 2449, 2438-2449. doi: 10.1002/hyp

Jones, J. B., Fisher, S. G., and Grimm, N. B. (1995). Vertical hydrologic exchange and ecosystem metabolism in a sonoran desert stream. Ecology $76,942-952$

Kendall, C. (1998). “Tracing nitrogen sources and cycling in catchments," in Isotope Tracers in Catchment Hydrology eds C. Kendall and J. J. McDonnell (Amsterdam: Elsevier Science B.V.), 519-576.

Knapp, J. L. A., and Cirpka, O. A. (2018). A critical assessment of relating resazurin - resorufin experiments to reach-scale metabolism in lowland streams. J. Geophys. Res. Biogeosci. 123, 3538-3555. doi: 10.1029/2018JG004797

Knapp, J. L. A., González-Pinzón, R., and Haggerty, R. (2018). The resazurin-resorufin system: insights from a decade of "smart" tracer development for hydrologic applications. Water Resour. Res. 54, 1-13. doi: 10.1029/2018WR023103

Krause, S, Hannah, D. M., Fleckenstein, J. H., Heppell, C. M., Kaeser, D., Pickup, R., et al. (2011). Inter-disciplinary perspectives on processes in the hyporheic zone. Ecohydrology 4, 481-499. doi: 10.1002/eco

Krause, S., Tecklenburg, C., Munz, M., and Naden, E. (2013). Streambed nitrogen cycling beyond the hyporheic zone: flow controls on horizontal patterns and depth distribution of nitrate and dissolved oxygen in the upwelling 
groundwater of a lowland river. J. Geophys. Res. Biogeosci. 118, 54-67. doi: 10.1029/2012JG002122

Lansdown, K., Heppell, C. M., Dossena, M., Ullah, S., Heathwaite, A. L., Binley, A., et al. (2014). Fine-scale in situ measurement of riverbed nitrate production and consumption in an armored permeable riverbed. Environ. Sci. Technol. 48, 4425-4434. doi: 10.1021/es4056005

Lautz, L. K., and Fanelli, R. M. (2008). Seasonal biogeochemical hotspots in the streambed around restoration structures. Biogeochemistry 91, 85-104. doi: 10.1007/s10533-008-9235-2

Lees, M. J., Camacho, L. A., and Chapra, S. (2000). On the relationship of transient storage and aggregated dead zone models of longitudinal solute transport in streams. Water Resour. Res. 36, 213-224.

Lemke, D., Schnegg, P. A., Schwientek, M., Osenbrück, K., and Cirpka, O. A. (2013). On-line fluorometry of multiple reactive and conservative tracers in streams. Environ. Earth Sci. 69, 349-358. doi: 10.1007/s12665-013-2305-3

Marzadri, A., Tonina, D., and Bellin, A. (2012). Morphodynamic controls on redox conditions and on nitrogen dynamics within the hyporheic zone: application to gravel bed rivers with alternate-bar morphology. J. Geophys. Res. 117:G00N10. doi: 10.1029/2012JG001966

Marzadri, A., Tonina, D., Bellin, A., and Tank, J. L. (2014). A hydrologic model demonstrates nitrous oxide emissions depend on streambed morphology. Geophys. Res. Lett. 41, 5484-5491. doi: 10.1002/2014GL060732.Rivers

Mason, S. J. K., Mcglynn, B. L., and Poole, G. C. (2012). Hydrologic response to channel reconfiguration on Silver Bow Creek, Montana. J. Hydrol. 438-439, 125-136. doi: 10.1016/j.jhydrol.2012.03.010

McAuliffe, C. (1971). Gas chromatographic determination of solutes by multiple phase equilibriume. Chem. Technol. 1, 46-51.

McClain, M. E., Boyer, E. W., Dent, C. L., Gergel, S. E., Grimm, N. B., Groffman, P. M., et al. (2003). Biogeochemical hot spots and hot moments at the interface of terrestrial and aquatic ecosystems. Ecosystems 6, 301-312. doi: 10.1007/s10021-003-0161-9

McMahon, P. B., and Böhlke, J. K. (1996). Denitrification and mixing in a streamaquifer system: effects on nitrate loading to surface water. J. Hydrol. 186, 105-128. doi: 10.1016/S0022-1694(96)03037-5

Moore, R. D. (2005). Introduction to salt dilution gauging for streamflow measurement part 3: Slug injection using salt in solution. Streamline Watershed Manage. Bull. 8, 1-6. https://www.uvm.edu/bwrl/lab_docs/protocols/2005_ Moore_Slug_salt_dilution_gauging_volumetric_method_Streamline.pdf

Mulholland, P. J., Marzolf, E. R., Webster, J. R., and Hart, D. R. (1997). Evidence that hyporheic zones increase heterotrophic metabolism and phosphorus uptake in forest streams. Limnol. Oceanogr. 42, 443-451. doi: 10.4319/lo.1997.42.3.0443

Oksanen, J., Blanchet, F. G., Friendly, M., Kindt, R., Legendre, P., McGlinn, D., et al. (2020). vegan: Community Ecology Package. R package version 2.5-7. Available online at: https://CRAN.R-project.org/package=vegan

Pinay, G., O'Keefe, T., Edwards, R., and Naiman, R. (2009). Nitrate removal in the hyporheic zone of a salmon river in Alaska. River Res. Appl. 25, 367-375. doi: $10.1002 / \mathrm{rra}$

Quick, A. M., Reeder, W. J., Farrell, T. B., Tonina, D., Feris, K. P., and Benner, S. G. (2016). Controls on nitrous oxide emissions from the hyporheic zones of streams. Environ. Sci. Technol. (3). doi: 10.1021/acs.est.6b02680

R Development Core Team (2011). R: A Language and Environment for Statistical Computing. Vienna: R Foundation for Statistical Computing. Available online at: https://www.r-project.org

Raymond, P. A, Hartmann, J., Lauerwald, R., Sobek, S., McDonald, C., Hoover, M., et al. (2013). Global carbon dioxide emissions from inland waters. Nature 503, 355-359. doi: 10.1038/nature 12760

Reeder, W. J., Quick, A. M., Farrell, T. B., Benner, S. G., Feris, K. P., Marzadri, A., et al. (2018). Hyporheic source and sink of nitrous oxide. Water Resour. Res. 54, 1-16. doi: 10.1029/2018WR022564

Rivett, M., Elllis, P. A., Greswell, R. B., Ward, R., Roche, R., Cleverly, M., et al. (2008). Cost-effective mini drive-point piezometers and multilevel samplers for monitoring the hyporheic zone. Q. J. Eng. Geol. Hydrogeol. 41, 49-60. doi: 10.1144/1470-9236/07-012

Schmadel, N. M., Ward, A. S., Kurz, M. J., Fleckenstein, J. H., Zarnetske, J. P., Hannah, D. M., et al. (2016). Stream solute tracer timescales changing with discharge and reach length confound process interpretation. Water Resour. Res. 52, 3227-3245. doi: 10.1002/2015WR018062.Received
Seitzinger, S., Harrison, J., Bohlke, J., Bouwman, A., Lowrance, R., Peterson, B., et al. (2006). Denitrification across landscaes and waterscapes: a synthesis. Ecol. Appl. 16, 2064-2090. doi: 10.1890/1051-0761(2006)016[2064:DALAWA]2.0. $\mathrm{CO} ; 2$

Stanley, E. H., Casson, N. J., Christel, S. T., Crawford, J. T., Loken, L. C., and Oliver, S. K. (2016). The ecology of methane in streams and rivers: patterns, controls, and global significance. Ecol. Monogr. 86, 146-171. doi: 10.1890/151027.1

Thomas, S. A., Valett, H. M., Webster, J. R., and Mulholland, P. J. (2003). A regression approach to estimating reactive solute uptake in advective and transient storage zones of stream ecosystems. Adv. Water Resour. 26, 965-976. doi: 10.1016/S0309-1708(03)00083-6

Trimmer, M., Grey, J., Heppell, C. M., Hildrew, A. G., Lansdown, K., Stahl, H., et al. (2012). River bed carbon and nitrogen cycling: state of play and some new directions. Sci. Total Environ. 434, 143-158. doi: $10.1016 /$ j.scitotenv.2011.10.074

Trimmer, M., Risgaard-Petersen, N., Nicholls, J., and Engström, P. (2006). Direct measurement of anaerobic ammonium oxidation (anammox) and denitrification in intact sediment cores. Mar. Ecol. Progr. Ser. 326, 37-47. doi: $10.3354 /$ meps326037

Triska, F. J., Duff, J. H., and Avanzino, R. J. (1993). Patterns of hydrological exchange and nutrient transformation in the hyporheic zone of a gravelbottom stream: examining terrestrial-aquatic linkages. Freshwater Biol. 29, 259-274

Vidon, P., and Serchan, S. (2016a). Impact of stream geomorphology on greenhouse gas concentration in a New York mountain stream. Water Air Soil Pollut. 227:878. doi: 10.1007/s11270-016-3131-5

Vidon, P., and Serchan, S. (2016b). Landscape geomorphic characteristic impacts on greenhouse gas fluxes in exposed stream and riparian sediments. Environ. Sci. Process. Impac. 18, 844-853. doi: 10.1039/c6em00162a

Villa, J. A., Smith, G. J., Ju, Y., Renteria, L., Angle, J. C., Arntzen, E., et al. (2020). Methane and nitrous oxide porewater concentrations and surface fluxes of a regulated river. Sci. Total Environ. 715:136920. doi: 10.1016/j.scitotenv.2020.136920

Wagner, B. J., and Harvey, J. W. (1997). Experimental design for estimating parameters of rate-limited mass transfer: analysis of stream tracer studies. Water Resour. Res. 33, 1731-1741. doi: 10.1029/97WR01067

Ward, A. S., Gooseff, M. N., Voltz, T. J., Fitzgerald, M., Singha, K., and Zarnetske, J. P. (2013a). How does rapidly changing discharge during storm events affect transient storage and channel water balance in a headwater mountain stream? Water Resour. Res. 49, 5473-5486. doi: 10.1002/wrcr.20434

Ward, A. S., Payn, R. A., Gooseff, M. N., Mcglynn, B. L., Bencala, K. E., Kelleher, C. A., et al. (2013b). Variations in surface water-ground water interactions along a headwater mountain stream: comparisons between transient storage and water balance analyses. Water Resour. Res. 49, 3359-3374. doi: 10.1002/wrcr.20148

Wilhelm, E., Battino, R., and Wilcock, R. J. (1977). Low-pressure solubility of gases in liquid water. Chem. Rev. 77, 219-262. doi: 10.1021/cr60306a003

Wrage, N., Velthof, G. L., Van Beusichem, M. L., and Oenema, O. (2001). Role of nitrifier denitrification in the production of nitrous oxide. Soil Biol. Biochem. 33, 1723-1732. doi: 10.1016/S0038-0717(01)00096-7

Zarnetske, J. P., Haggerty, R., Wondzell, S. M., and Baker, M. A. (2011). Dynamics of nitrate production and removal as a function of residence time in the hyporheic zone. J. Geophys. Res. 116:G01025. doi: 10.1029/2010JG 001356

Conflict of Interest: The authors declare that the research was conducted in the absence of any commercial or financial relationships that could be construed as a potential conflict of interest.

The handling Editor declared a past co-authorship with one of the authors SK.

Copyright (c) 2021 Comer-Warner, Blaen, Brekenfeld, Gooddy, Lovell, Khamis, Bryden and Krause. This is an open-access article distributed under the terms of the Creative Commons Attribution License (CC BY). The use, distribution or reproduction in other forums is permitted, provided the original author(s) and the copyright owner(s) are credited and that the original publication in this journal is cited, in accordance with accepted academic practice. No use, distribution or reproduction is permitted which does not comply with these terms. 